\title{
THE INFLUENCE OF EXPERIENTIAL MARKETING ON REPURCHASE INTENTION (STUDY AT MARASOE)
}

\author{
Reynaldi Eka Putra ${ }^{1)}$, Pratami Wulan Tresna ${ }^{2)}$, Cecep Safaatul Barkah ${ }^{3)}$, Arianis Chan ${ }^{4)}$ \\ 1,2,3,4) Universitas Padjadjaran, Jatinangor, Indonesia \\ Corresponding author: reynaldi19001@mail.unpad.ac.id
}

\begin{abstract}
Marasoe is an online fashion business that sells women's products. In this era, the increasing number of fashion businesses makes Marasoe have to do experiential marketing to make a memorable experience for the consumer. A memorable experience will lead to a positive response, such as a repurchase intention. This research investigates the influence of experiential marketing on repurchase intention at Marasoe. This study uses quantitative research methods, and data gained using primary sources from questionnaires and secondary. The total sample involves 83 respondents who were selected by the purposive sampling technique. This study shows that experiential marketing has a significant influence on repurchase intention, either partially or simultaneously.
\end{abstract}

Keywords: Experiential Marketing, Repurchase Intention, Consumers, Marasoe

\section{Introduction}

The success of a business depends on ideas and opportunities. An entrepreneur must be able to create new ideas that can provide value to consumers, and an entrepreneur must be able to see business opportunities that are currently developing. One of the business sectors overgrowing is the business in the fashion sector. The fashion business development is marked by the increasing number of fashion businesses present in this era of globalization, which has led to increasingly fierce competition faced by every fashion business. To face increasingly fierce competition, every businessman in the fashion sector is competing to create various strategies innovations to survive in the midst of increasingly fierce competition and win the competition.

When consumers buy a product, consumers usually want the product that can provide benefits, both in the form of functional value and emotional value. If a business can provide both values, it will create a good experience for consumers when using these products and services. To create a memorable experience for consumers, marketers must do experiential marketing. According to Schmitt (1999) is an effort to create a consumer experience when using a product or service measured through five components, including sense, feel, think, act and relate. One indicator to determine business success is repurchase intention continuously (Yanto et al., 2020). The extraordinary experiences consumers receive from different services can increase their repurchase intention. When repurchasing a product from a company, repurchase intention is a consumer's assessment by considering the current situation and possible situation (Hellier et al., 2003). A satisfying buying experience is one of the reasons to stay interested in reusing the product which leads to repeat purchases.

Marasoe is one of the businesses engaged in an online fashion that sells women's clothing products. Marasoe was established in 2018 and initially only sold beauty products such as make-up and skin care. Along with time, in 2020, Marasoe switched to selling women's clothing products such as sweaters, flannel shirts, long-sleeved shirts, and vests. The reason the owner of Marasoe switched to selling women's clothing products was that the owner of Marasoe saw his friends who were consumptive in buying clothes and saw the broad market share of the business in the fashion sector, considering that fashion products are one of the primary needs for humans who continue to develop according to the times. Marasoe makes the products with a simple design concept and a selection of pastel colors suitable for all skin tones so that consumers who wear them can be more confident with the color of their clothes when used. Marasoe wants sales to continue to increase every month, they also want their products to be better known to many people, and many people make Marasoe their main preference in buying clothing products. To achieve this goal, the concept of experiential marketing can shape the experience for consumers when using Marasoe products. If consumers are satisfied when using Marasoe products, they can make Marasoe their primary preference in buying clothing products and cause repeat purchases to increase Marasoe sales.

Based on this phenomenon, the researcher wants to examine how much influence experiential marketing on Marasoe. In the end, consumers get a memorable experience while using Marasoe products. The memorable experience received by consumers is expected to generate consumer repurchase intention in Marasoe products. With this research, it is hoped that it can help Marasoe owners determine the strategy that will be used to add value to their consumers.

\section{Literature Review \\ Experiential Marketing}


Experiential Marketing (Smilansky, 2017) identifies consumer needs profitably and makes consumers interesting through two-way communication that builds brand personality and adds value to the consumers. Meanwhile, according to Schmitt (1999), experiential marketing is an effort to make a consumer experience when the consumers use a product or service. There are 4 keys characteristics of experiential marketing (Schmitt, 1999), including the following :

1. Focus on consumers experience

This experience can connect business entities and their products with consumer lifestyles that encourage personal purchases within the scope of their business.

2. Focus on consumer consumption as a holistic experience.

Consumers want a product that is seen from the overall situation when using the product and from experience gained when using the product.

3. Recognize rational and emotional aspects as triggers for consumption.

From the perspective of experiential marketing, consumers are seen from the rational side and the emotional side. Consumers prefer to be stimulated and influenced emotionally, therefore do not treat consumers only as decision-makers in their choices.

4. Methods and tools are electic

Methods and tools for measuring one's experience are more eclectic, which means they depend more on the object to be measured or focus on each situation that occurs rather than using the same standard.

\section{The Purpose of Experiential Marketing}

Experiential marketing carried out by a business has the following objectives (Smilansky, 2017) :

1. Building a brand personality.

2. Create a memorable experience.

3. Increase consumer loyalty.

4. Creating worth of mouth.

5. Increase sales and brand awareness.

\section{Measurement of Experiential Marketing}

Schmitt (1999) states that experiential marketing can be measured using five components, including the following :

1. Sense Experience

It is effort to make experiences through the five senses; sight, smell, hearing, touch, and taste. Sense is used to differentiate the companies and their products and encourage the buyer to use their products and give value to the buyer.

2. Feel the experience

It is effort to make experiences through feelings and emotions that aim to stimulate emotional stimuli that can affect consumers' moods \& emotions.

3. Think experience

It is an effort to make experiences through the mindset of future, value, focus, quality, and growth. The goal is to make the consumers think and be interested in using the product.

4. Act experience

It is an effort to make experiences through the behavior patterns and lifestyles to give an experience and good impression on behavioral patterns and lifestyles.

5. Relate an experience

It is a composite of the four components of sense, feel, think, and act components. In general, related experiences convey relationships with other people. The purpose of related experience is to connect buyers with the social environment that the brand of a product reflects

\section{Repurchase Intention}

Repurchase intention is consumer behavior in which consumers respond positively has been given by the company and are interested in repurchasing the product (Cronin et al. 1992). Meanwhile, Hellier et al. (2003) defining repurchase intention as a consumer's assessment when buying the products or services from the same business and tends to be carried out periodically by considering the current situation and possible conditions. From these two definitions, it can be concluded that repurchase intention is the application of the results of consumers' positive responses to the product by considering several things and taking positive actions related to the company or product by making repeated purchases.

Kotler \& Keller (2012) said that factors influence consumer buying interest for repeat purchases, namely psychological factors, personal factors, and social factors. Consumers who are satisfied in buying a product will strengthen their purchase intention and recommend the brand or product they are using. Satisfied consumers will make their purchases for the second time, the third time, and continuously without considering several things they did when they first bought. Meanwhile, disappointed consumers will tend to return the product or will not even repurchase the product. 


\section{Conceptual Framework}

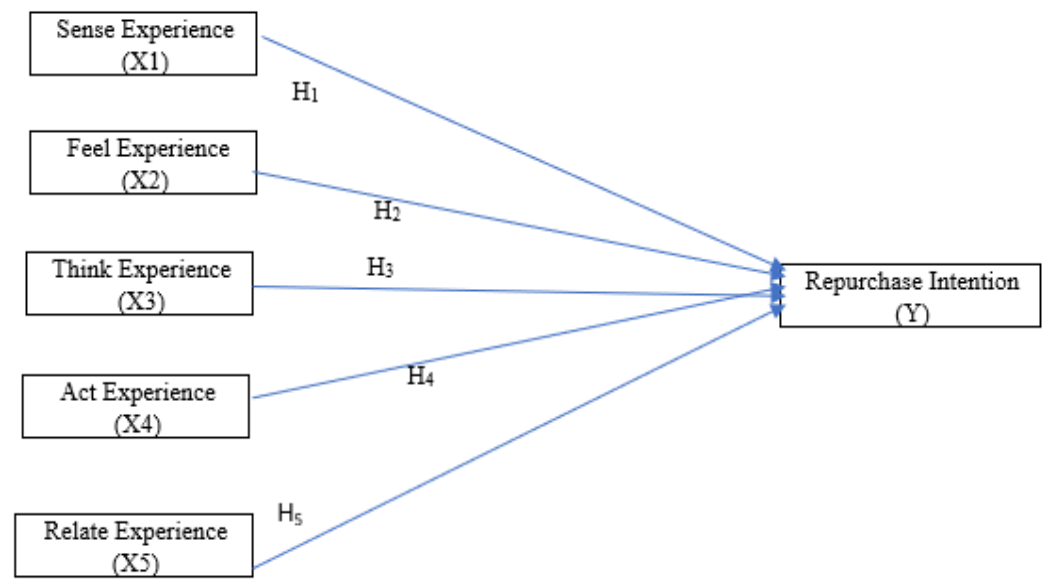

Figure 1. Conceptual Framework

\section{Hypothesis}

H1: Sense experience has a significant influence on repurchase intention.

$\mathrm{H} 2$ : Feel experience has a significant influence on repurchase intention.

H3: Think experience has a significant influence on repurchase intention.

$\mathrm{H} 4$ : Act experience has a significant influence on repurchase intention.

H5: Relate experience has a significant influence on repurchase intention.

\section{Research Methods \\ Types of Research}

This research uses a quantitative method to survey a particular population or sample and requires research instruments and quantitative data analysis. (Sugiyono, 2011).

\section{Population and Sampling Technique}

The population in this research is all Marasoe consumers. The total population is obtained from purchase data in November 2021, which is 458. After knowing the number of the population owned, it is necessary to know the total samples needed in this research. The sampling technique used is a non-probability sampling that does not provide similar opportunities for each member of the population selected as a sample (Hadi, 2006). According to the research, the type of non-probability sampling with the characteristics (Jupp, 2006). The characteristics needed in this study include women aged 12-27 years who have bought Marasoe products at least once. The researcher used the Slovin formula to calculate the number of samples with the following results :

$$
n=\frac{W}{1+\left(N \cdot\left[e^{2}\right)\right.}=\frac{458}{1+\left[458 \cdot\left(0.1^{2}\right)_{3}\right.}=82,078
$$

Description :

$\mathrm{N}=$ Total population

$\mathrm{n}=$ Total samples

$\mathrm{e}=$ error tolerance limit $(10 \%)$

Based on the sample calculation using the Slovin formula, the sample in this study was 82,078 , which was rounded to 83 . This means that the sample of this study was at least 83 Marasoe consumers.

\section{Data Sources and Data Collective Technique}

This study uses primary and secondary data sources. Primary data sources were obtained from questionnaires distributed online via a google form. The questions listed in the questionnaire are derivatives of the indicators for each variable. The questionnaire was distributed using answer choices using a Likert scale with levels :

Table 1. Likert Scale 


\begin{tabular}{|c|c|}
\hline Rate & Description \\
\hline 1 & Very Disagree \\
\hline 2 & Disagree \\
\hline 3 & Neutral \\
\hline 4 & Agree \\
\hline 5 & Very Agree \\
\hline
\end{tabular}

The results obtained as many as 83 respondents' answers, which will be processed data. The researcher also uses secondary data from several journal references and books related to the research.

\section{Data Analysis Method}

Data analysis in this research was carried out by several techniques, including validity test, reliability test, normality test, multicollinearity test, multiple linear regression analysis, T-test (partial test), F-test (F-test), and coefficient of determination.

\section{Result and Discussion}

\section{Validity and Reliability Test}

A validity test is used to identify all question items (indicators) of each variable used in this study whether the questionnaire questions are valid (Ghozali, 2011). Each question item (indicator) of each variable is considered valid if the value of Recount is > Rtable.

Table 2. Validity Test Results

\begin{tabular}{|c|c|c|c|c|}
\hline Variable & Indicator & $\mathrm{R}_{\text {count }}$ & $\mathrm{R}_{\text {table }}$ & Description \\
\hline \multirow[t]{4}{*}{ Sense Experience } & X1 1 & 0,535 & 0,1818 & Valid \\
\hline & $\mathrm{X} 12$ & 0,825 & 0,1818 & Valid \\
\hline & X1 3 & 0,518 & 0,1818 & Valid \\
\hline & $\mathrm{X} 14$ & 0,655 & 0,1818 & Valid \\
\hline \multirow[t]{2}{*}{ Feel Experience } & X2_1 & 0,629 & 0,1818 & Valid \\
\hline & $\mathrm{X} 22$ & 0,670 & 0,1818 & Valid \\
\hline \multirow{4}{*}{ Think Experience } & X31 & 0,398 & 0,1818 & Valid \\
\hline & $\mathrm{X} 32$ & 0,779 & 0,1818 & Valid \\
\hline & $\mathrm{X} 33$ & 0,864 & 0,1818 & Valid \\
\hline & X3 4 & 0,396 & 0,1818 & Valid \\
\hline \multirow[t]{2}{*}{ Act Experience } & X4 1 & 0,564 & 0,1818 & Valid \\
\hline & $\mathrm{X} 422$ & 0,851 & 0,1818 & Valid \\
\hline Relate Experience & X5 1 & 0,583 & 0,1818 & Valid \\
\hline \multirow{5}{*}{ Repurchase Intention } & Y 1 & 0,853 & 0,1818 & Valid \\
\hline & $\mathrm{Y} 2$ & 0,860 & 0,1818 & Valid \\
\hline & Y 3 & 0,884 & 0,1818 & Valid \\
\hline & Y 4 & 0,836 & 0,1818 & Valid \\
\hline & Y 5 & 0,634 & 0,1818 & Valid \\
\hline
\end{tabular}

The result of validity shows that all question items (indicators) on all research variables produce a Recount value that is greater than the R-table value. Thus, all the question items (indicator) measured on each variable are considered valid. A reliability test is used to measuring the instrument is reliable or not. The reliability test measured uses Cronbach's alpha value. If Cronbach's alpha value is $>0.6$, the question items are considered reliable. Based on table 3 below, all the question items on each variable are declared reliable because Cronbach's alpha value is $0.936>0.6$.

Table 3. Reliability Test

\begin{tabular}{r|r}
$\begin{array}{c}\text { Cronbach's } \\
\text { Alpha value }\end{array}$ & $\begin{array}{c}\text { Number of } \\
\text { Items }\end{array}$ \\
\hline .936 & 18 \\
\hline
\end{tabular}

\section{Normality Test}

A normality test was carried out to determine the two types of variables have a standard data distribution or not. To determine the normality of this study using the Kolmogorov-Smirnov test. The results tested using Kolmogorov-Smirnov Test in table 4 below, that the research data has been customarily distributed. 
Table 4. Kolmogorov Smirnoff's Normality Test

\begin{tabular}{llr} 
& & Unstandardized Residual \\
\hline $\mathrm{N}$ & & 83 \\
\hline Normal Parameters ${ }^{\mathrm{a}, \mathrm{b}}$ & Mean & .0000000 \\
\cline { 2 - 3 } & Std. Deviation & 2.35021161 \\
\hline Most Extreme Differences & Absolute & .098 \\
\cline { 2 - 3 } & Positive & .067 \\
\cline { 2 - 3 } & Negative & -.098 \\
\hline Test Statistic & & .098 \\
\hline Asymp. Sig. (2-tailed) & & $.146^{\circ}$ \\
a. Test distribution is Normal. & & \\
b. Calculated from data. & & \\
c. Lilliefors Significance Correction. & & \\
\hline
\end{tabular}

\section{Multicollinearity Test}

A multicollinearity test was carried out to scrutinize independent correlation variables not. This test was carried out to identify the tolerance value (TOL) and VIF Value. If the tolerance value is higher than 0.1 and VIFvvalue is lower than 10, it means there is no multicollinearity between independent variables.

Table 5. Multicollinearity Test Results

\begin{tabular}{|c|c|c|c|}
\hline \multirow[b]{2}{*}{ Model } & & \multicolumn{2}{|c|}{ Collinearity Statistics } \\
\hline & & Tolerance Value & $\begin{array}{c}\text { VIF } \\
\text { Value }\end{array}$ \\
\hline \multirow[t]{6}{*}{1} & (Constant) & & \\
\hline & Sense Experience & .415 & 2.410 \\
\hline & Feel Experience & .496 & 2.018 \\
\hline & Think Experience & .330 & 3.030 \\
\hline & Act Experience & .406 & 2.460 \\
\hline & Relate Experience & 7.05 & 1.417 \\
\hline
\end{tabular}

Table 5 shows that VIF variable sense-experience (X1), feel experience (X2), thing experience (X3), actxexperience (X4), and related experience (X5) $<10$ and the tolerance value of all X variables $>0.1$, then the data does not occur multicollinearity.

\section{Multiple Linier Regression}

Multiple linear regression is a linear regression model that involves more than one independent variable (Jobson, 2012). This test was carried out to scrutinize the effect of sense-experience (X1), feel experience (X2), thing experience (X3), act experience (X4), related experience (X5) on repurchase intention (Y) at Marasoe. The results of multiple linear regression analysis using SPSS version 24 software can be seen from the table below.

\begin{tabular}{|c|c|c|c|c|c|}
\hline \multirow[b]{2}{*}{ Model } & \multicolumn{2}{|c|}{$\begin{array}{l}\text { Unstandardized } \\
\text { Coefficients }\end{array}$} & \multirow{2}{*}{$\begin{array}{c}\text { Standardized } \\
\text { Coefficients } \\
\text { Beta Value }\end{array}$} & \multirow[b]{2}{*}{$\mathrm{t}$} & \multirow[b]{2}{*}{ Significant. } \\
\hline & B Value & $\begin{array}{l}\text { Standard } \\
\text { Error }\end{array}$ & & & \\
\hline (Constant) & -11.930 & 2.657 & & -4.490 & 0.000 \\
\hline $\begin{array}{l}\text { Sense } \\
\text { experience } \\
\text { (X1) }\end{array}$ & 0.474 & 0.172 & 0.269 & 2.750 & 0.007 \\
\hline $\begin{array}{l}\text { Feel } \\
\text { experience } \\
\text { (X2) }\end{array}$ & 0.373 & 0.295 & 0.106 & 1.865 & 0.090 \\
\hline $\begin{array}{l}\text { Think } \\
\text { experience } \\
\text { (X3) }\end{array}$ & 0.667 & 0.248 & 0.287 & 2.685 & 0.009 \\
\hline $\begin{array}{l}\text { Act experience } \\
\text { (X4) }\end{array}$ & 0.653 & 0.288 & 0.223 & 2.270 & 0.026 \\
\hline $\begin{array}{l}\text { Relate } \\
\text { experience } \\
\text { (X5) }\end{array}$ & 0.600 & 0.392 & 0.113 & 1.928 & 0.081 \\
\hline
\end{tabular}

The results of the table above indicate the multiple linear regression model in this research is as follows: 


\section{$\mathrm{Y}=-11,930+0,474 \mathrm{X} 1+0,373 \mathrm{X} 2+0,667 \mathrm{X} 3+0,653 \mathrm{X} 4+0,600 \times 5$}

a. The constant value $(\alpha)$ is -11.930 , indicating no influence in X1, X2, X3, X4, and X5.

b. Sense experience variable (X1) has a value is 0.474 , which indicates sense experience variable (X1) has a positive influence on repurchase intention $(\mathrm{Y})$. If the sense experience variable (X1) increases by one Likert scale, then the repurchase intention variable (Y) will be increased by 0.474 if the other variables are 0 .

c. Feel experience variable (X2) has a value is 0.373 , which indicates eel experience variable (X2) has a positive influence on repurchase intention (Y). If the feel experience variable (X2) increases by one Likert scale, then the repurchase intention variable (Y) will be increased by 0.373 if the other variables are 0 .

d. Think experience variable (X3) has a value is 0.667 , which indicates think experience variable (X3) has a positive influence on repurchase intention (Y). If the think experience variable (X3) increases by one Likert scale, then the repurchase intention variable (y) will be increased by 0.667 if the other variables are 0 .

e. The act experience variable $(\mathrm{X} 4)$ has a value is 0.653 , which indicates the act experience variable positively influences repurchase intention (Y). If the act experience variable (X4) increases by one Likert scale, then the repurchase intention variable (Y) will be increased by 0.653 if the other variables are 0 .

f. Relate experience variable (X5) has a value is 0.600 , which indicates the related experience variable (X5) has a positive influence on repurchase intention (Y). If the related experience variable (X5) increases by one Likert scale, then the repurchase intention variable (Y) will increase by 0.600 if the other variables are 0.

\section{T-test}

The T-test in this research scrutinizes the partially significant influence of the independent variables on the dependent variable, namely variable sense (X1), feel (X2), think (X3), act (X4), relate (X5) on repurchase intention (Y). The basis for making the decision is :

1. Significance value is lower than 0.10 , or $\mathrm{t}$-count is higher than t-table, which means variable $\mathrm{X}$ influences variable Y.

2. Significance value is higher than 0,10 , or $\mathrm{t}$-count is lower than $\mathrm{t}$-table, which means variable $\mathrm{X}$ does not influence variable $\mathrm{Y}$.

From table 6, we can see the results of the t-test is :

1. $\mathrm{X} 1$ has a significant value on $\mathrm{Y}$ is $0.007<0.10$ or the $\mathrm{t}$-count is $2.750>1.664$, so it means that $\mathrm{H} 1$ is accepted, it indicates that $\mathrm{X} 1$ influences variable $\mathrm{Y}$.

2. $\mathrm{X} 2$ has a significant value on $\mathrm{Y}$ is $0.090<0.10$ or the $\mathrm{t}$-count is $1.865>1.664$, so it means that $\mathrm{H} 2$ is accepted, it indicates that $\mathrm{X} 2$ influences variable $\mathrm{Y}$.

3. $\mathrm{X} 3$ has a significant value on $\mathrm{Y}$ is $0.009<0.10$ or the $\mathrm{t}$-count is $2.685>1.664$, so it means that $\mathrm{H} 3$ is accepted, it indicates that $\mathrm{X} 3$ influences variable $\mathrm{Y}$.

4. $\mathrm{X} 4$ has a significant value on $\mathrm{Y}$ is $0.026<0.10$ or the $\mathrm{t}$-count is $2.270>1.664$, so it means that $\mathrm{H} 4$ is accepted, it indicates that $\mathrm{X} 4$ has an influence of $\mathrm{X} 4$ on variable $\mathrm{Y}$

5. $\mathrm{X} 5$ has a significant value on $\mathrm{Y}$ is $0.081<0.10$ or the $\mathrm{t}$-count is $1.928>1.664$, so it means that H5 is accepted, it indicates that X5 has an influence of X5 on variable $\mathrm{Y}$.

\section{F-test}

F-test in this study to scrutinize simultaneously there is an influence of the independent variable on the dependent variable or not. The basis for making the decision is :

1. Significance value is lower than 0.10 , or Fount is higher F-table, there is a simultaneous influence of the $\mathrm{X}$ variable on variable $\mathrm{Y}$.

2. Significance value is lower than 0.10 or F-count is lower F-table, there is no simultaneous influence of the $\mathrm{X}$ variable on variable $\mathrm{Y}$.

Table 7. F-test

\begin{tabular}{|l|l|r|r|r|r|r|}
\hline \multicolumn{2}{|l|}{ Model } & $\begin{array}{c}\text { Sum of } \\
\text { Squares }\end{array}$ & df & $\begin{array}{c}\text { Mean } \\
\text { Square }\end{array}$ & \multicolumn{1}{c|}{ F } & Sig. \\
\hline \multirow{2}{*}{1} & Regression & 1038.037 & 5 & 207.607 & 35.294 & $.000^{\text {b }}$ \\
\cline { 2 - 7 } & Residual & 452.927 & 77 & 5.882 & & \\
\cline { 2 - 7 } & Total & 1490.964 & 82 & & & \\
\hline
\end{tabular}


The table above indicates that the significance value for the influence of $\mathrm{X} 1, \mathrm{X} 2, \mathrm{X} 3, \mathrm{X} 4, \mathrm{X} 5$ simultaneously on variable $\mathrm{Y}$ is 0.000 is lower than 0.10 . F count is 5.882 higher than $\mathrm{F}$ table 1.92 , so it conclude that $\mathrm{H} 6$ is accepted, there is indicate of influence of $\mathrm{X} 1, \mathrm{X} 2, \mathrm{X} 3, \mathrm{X} 4, \mathrm{X} 5$ simultaneously on variable Y.

\section{Coefficient of Determination}

This test is used to measure the contribution of the independent variables to the dependent variable.

Table 8. Coefficient of Determination Results

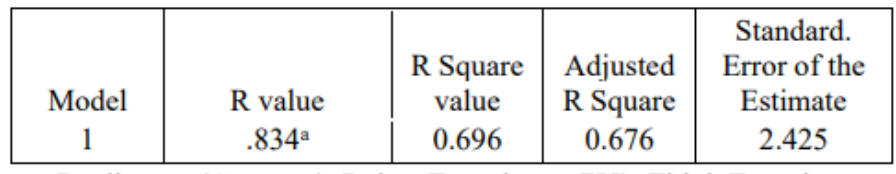

a. Predictors: (Constant), Relate Experience (X5), Think Experience (X3), Feel Experience (X2), Sense Experience (X1), Act Experience (X4)

The table above shows that the coefficient of determination value (Adjusted R Square) is 0.676. It indicates the influence of variables X1, X2, X3, X4, X5 simultaneously on variable Y is $67.6 \%$. Meanwhile, $33.4 \%$ is affected by other variables not examined in this research.

\section{Conclusion}

Based on the results of research that has been done, the authors can provide the following conclusions :

1. Validity and reliability tests were carried out to show that all questions (indicators) on each variable are declared valid and reliable.

2. The data in this study were typically distributed after being tested using Kolmogorov Smirnov in normality test.

3. A multicollinearity test was carried out in this research shows that there is no multicollinearity in the data of this research.

4. The T-test that was carried out in this research shows that the five independent variables partially influence the dependent variable.

5. The F-test that was carried out shows that the five independent variables simultaneously influence the dependent variable.

6. The results of the coefficient of determination in this study indicate that the value of the coefficient of determination is 0.676 .

\section{Suggestion}

The results of research shows the effect of experiential marketing on repurchase intention; the researchers can provide suggestions in the form of strategies that can be applied in Marasoe, as follows :

1. Use filter features photographic techniques, and add visual aesthetics to social media posts to attract a larger audience. This is done for consumers when they see Marasoe product posts on social media so that they buy. This is done to enhance the sensory experience.

2. They are maintaining service quality such as handling consumer complaints properly, answering all questions with a fast response, and being friendly to consumers. This is to make a positive experience for consumers when buying the products at Marasoe, and if consumers are satisfied with the services provided by Marasoe, consumers will repurchase. This is related to maintaining the feel experience for Marasoe.

3. To create a think experience, it can be done by innovating products using wrinkle-less product materials that make the products look neat and do not look wrinkled quickly. On the other hand, Marasoe can use product materials that always make consumers feel calm in any condition, considering that Indonesia is a tropical area that is constantly exposed to sunlight throughout the year.

4. To create an act experience, it can be done by making products that follow the trends and developments of the times, considering that fashion changes very quickly. In addition, it can display various product usage references on social media content that suits consumer tastes.

5. Utilize the broadcast feature on instant messenger applications such as an official account Line as a medium for sharing the latest information about the latest Marasoe products and promo information. In addition, Marasoe can hold periodic quizzes on social media with prizes. These efforts are related to creating related experiences so that Marasoe owners have a closer relationship with consumers.

\section{References}

Cronin Jr, J. J., \& Taylor, S. A. (1992). Measuring service quality: a reexamination and extension. Journal of Marketing, 56(3), 55-68 
Ghozali, Imam. (2011). Aplication Multivariate Analysis With SPSS Program. Semarang: Badan Penerbit Universitas Diponegoro.

Hadi, S. (2006). Research Methodology, 10th edition. Yogyakarta: Andi Offset.

Hellier, P. K., et al. (2003). Customer Repurchase Intention: A General Structural Equation Model. European Journal of Marketing, 37(11/12), 1762-1800.

Jobson, J. (2012). Applied Multivariate Data Analysis: Regression and Experimental Design. Germany: Springer New York.

Jupp, V. (2006). The SAGE Dictionary of Social Research Methods. United Kingdom: SAGE Publications.

Kotler, P. and Keller, K. L. (2012). Marketing Management, 14th Edition. New Jersey: Prentice-Hall.

Prianka, D., Ku, T. H., \& Cheng, C. Y. (2017). OE-6 Building a Personal Brand on Social Media from Experiential Marketing Perspective-A Case Study on Indonesia's Fashion Instagrammers.

Prianka, D. (2021). Instagram Brand Activation for Fashion Start Ups with Experiential Marketing. Teknologi dan Kejuruan: Jurnal Teknologi, Kejuruan, dan Pengajarannya, 44(1), 10-20.

Schmitt, B. (1999). Experiential marketing. Journal of marketing management, 15(1-3), 53-67.

Schmitt, B., \& Zarantonello, L. (2013). Consumer experience and experiential marketing: A critical review. Review of marketing research.

Smilansky, S. (2017). Experiential marketing: A practical guide to interactive brand experiences. Kogan Page Publishers.

Sugiyono. (2011). Quantitative, Qualitative, and R\&D Research Methods. Bandung: Alfabeta.

Wu, M. Y., \& Tseng, L. H. (2015). Customer satisfaction and loyalty in an online shop: An experiential marketing perspective. International Journal of Business and Management, 10(1), 104.

Yanto, B. T., Lindawati, T., \& Pradana, D. W. (2020). EXPERIENTIAL MARKETING AND EXPERIENTIAL VALUE, HOW DOES IT IMPACT ON CONSUMER REPURCHASE INTENTIONS. RIMA-Research In Management and Accounting, 3(1), 34-42. 